\title{
Adriamycin - efficacy and possible adverse effects
}

\author{
Adriamycyna - skuteczność terapii a możliwe działania niepożądane
}

Agnieszka Pedrycz ${ }^{1} \mathrm{~A}, \mathrm{~B}$, Agnieszka Kramkowska D,E,F

\author{
1.Histology and Embryology Department with the Experimental Cytology Laboratory \\ of Medical University of Lublin
}

\begin{abstract}
Adriamycin (doxorubicin) is a chemical substance in the anthracycline class with a wide range of applications in oncology and hematology. The mechanism of action of Adriamycin is related to formation of irregular bonds between nucleobases of DNA and inhibition of key enzymes of DNA synthesis - topoisomerase I and II as well as to formation of free radicals damaging DNA.

A major limitation in the drug use is associated with its adverse effects such as cardiotoxicity and hepatotoxicity.

The mechanism of myocardial injury by Adriamycin is linked to an increase in oxidative stress associated with impaired mitochondrial function and structure.

Cardiotoxicity of anthracyclines is classified as: acute, chronic or late (delayed).

Hepatotoxicity of Adriamycin as a damage of the liver is associated with a dysfunction of this organ. Adriamycin studies have shown increased level of transaminase present in $40 \%$ of patients treated with Adriamycin. The state was transient and asympto matic, returning to the initial level even when treatment continued.

Knowledge of cancer diseases contributed to a successive creation of two improved forms of Adriamycin (doxorubicin) - nonpegylated and pegylated formulas of the drug.

The mechanism of anticancer effects of liposomal Adriamycin is similar to the mechanism of conventional Adriamycin, but placement of the molecules of active substance in liposomes has significant influence on the distribution of the drug.

In order to increase the distribution of the drug, a special form of liposomal Adriamycin has been created by covering the surface of the liposomes with a hydrophilic polymer - (MPEG). This process, known as pegylation, decreases the interactions between the lipid bilayer membrane and the plasma components. Pegylated form of the drug is associated with a higher incidence of acute complications.
\end{abstract}

Keywords: Adriamycin, cardiotoxicity, hepatotoxicity

\section{Streszczenie}

Adriamycyna (doksorubicyna) jest substancją należącą do grupy antracyklin o szerokim zastosowaniu w onkologii i hematologii. Mechanizm działania Adriamycyny polega na tworzeniu nieprawidłowych wiązań pomiędzy zasadami azotowymi DNA oraz hamowaniu kluczowych enzymów syntezy DNA - topoizomerazy I i II oraz tworzeniu wolnych rodników uszkadzających DNA.

Znacznym ograniczeniem w stosowaniu Adriamycyny są działania niepożądane tego leku, takie jak: kardiotoksyczność oraz hepatotoksyczność.

Mechanizm uszkodzenia mięśnia sercowego przez Adriamycynę polega na wywoływaniu stresu oksydacyjnego związanego z zaburzeniami funkcji i struktury mitochondriów.

Kardiotoksyczność antracyklin klasyfikowana jest, jako: ostra, przewlekła oraz późna.

Hepatotoksyczność Adriamycyny, polegająca na uszkodzeniu wątroby związana jest z upośledzoną funkcją tego narządu. Badania nad Adriamycyną pokazują, że zwiększony poziom aminotransferaz występuje u do 40\% pacjentów leczonych Adriamycyną, ale jest przemijający i przebiega bezobjawowo, powracający do stanu początkowego nawet przy kontynuacji leczenia.

Wiedza o chorobach nowotworowych przyczyniła się do powstania kolejno dwóch ulepszonych form Adriamycyny (doksorubicyny) - niepegylowanej i pegylowanej formuły tego leku.

Sposób działania przeciwnowotworowego Adriamycyny liposomalnej jest analogiczny do mechanizmu Adriamycyny konwencjonalnej, ale umieszczenie cząsteczek substancji czynnej w liposomach ma znaczący wpływ na dystrybucję leku.

W celu zwiększenia dystrybucji leku, wytworzono specjalną formę liposomalnej Adriamycyny poprzez pokrycie powierzchni liposomów hydrofilowym polimerem - (MPEG). Proces ten, nazywany pegylacją, powoduje zmniejszenie interakcji między podwójną warstwą lipidową a składnikami osocza. Forma pegylowana leku związana jest z częstszym występowaniem ostrych powikłań.

Słowa kluczowe: Adriamycyna, kardiotoksyczność, hepatotoksyczność

\section{Adriamycin}

Adriamycin (doxorubicin) belongs to the anthracycline class with strong anticancer activity. It was isolated for the first time from the culture of Streptomyces peucetius var. caesius by Arcamone and registered as a medicine in 1971 [1].

(C) 2016 Medical University of Lublin. This is an open access article distributed under the Creative Commons Attribution-NonComercial-No Derivs licence (http://creativecommons.org/licenses/by-nc-nd/3.0/) 
Adriamycin is a chemical substance with cycledependant and phase-specific mechanism of action consisting of the creation of irregular bonds between nucleobases of DNA and inhibition of key enzymes of DNA topoisomerase I and II as well as the formation of free radicals which damage DNA. Thanks to these highly selective properties, Adriamycin is widely used in oncology and hematology [2]. However, its anticancer mechanism of action is not fully understood. Certainly, inhibition of protein synthesis and DNA and RNA synthesis is responsible for most of the cytotoxic effects of Adriamycin.

The mechanism of action Adriamycin is based on its incorporation into DNA, causing disruption and fragmentation of the helix, which leads directly to inhibition of DNA replication thus preventing the transcription of DNA to RNA.

Hypothetically, insertion of the anthracycline molecule between adjacent base pairs of the DNA double helix prevents their unwinding for further replication [3].

Adriamycin, as an anticancer drug is used in the treatment of systemic breast cancer, ovarian cancer, sarcomas, leukemias, lymphomas [4].

It is administered by intravenous or intra-arterial drip infusion. Sometimes it may also be administered locally:

- into the tumour [5],

- into the bladder [6],

- intraperitoneally [7],

- intrapleurally in malignant pleural mesothelioma [8].

\subsection{The pharmacokinetic and pharmacodynamic properties of Adriamycin}

Adriamycin plasma clearance is in the range from 324 to $809 \mathrm{~mL} / \mathrm{min} / \mathrm{m}^{2}$. It is cleared from the plasma mainly in the form of doxorubicinol metabolite (DOX-OL) and excreted in bile. About $40 \%$ of the dose appears in the bile in 5 days, while only 5 to $12 \%$ of the drug and its metabolites appear in urine over the same period. Less than $3 \%$ of the dose was recovered as doxorubicinol (DOX-OL) in 7 days.

The initial distribution half-life of Adriamycin is about 5 minutes, suggesting a rapid uptake of the substance by the tissues. In contrast, the slow elimination from the tissues is reflected in the length of the terminal half-life ranging from 20 to 48 hours. The steady state distribution volume varies from 809 to $1214 \mathrm{~L} / \mathrm{m}^{2}$, and is related to extensive drug uptake into the tissue. The degree of binding of Adriamycin and its major metabolite to plasma proteins is approximately $74-76 \%$ and is independent of plasma concentration up to concentration of $1.1 \mu \mathrm{g} / \mathrm{mL}$.

Adriamycin was detected in lactating patient's milk, with peak milk concentration measured 24 hours after treatment about 4.4 times higher than corresponding plasma concentration. Adriamycin was detected in milk up to 72 hours after distribution of the drug at a dose of $70 \mathrm{mg} / \mathrm{m}^{2}$.

Adriamycin does not cross the blood - brain barrier.

Enzymatic reaction and cleavage of the daunosamine sugar moiety yields aglycones. This process is accompanied by formation of free radicals. Local production of free radicals can contribute to Adriamycin cardiotoxicity. Distribution of DOX-OL in the body of patients is limited by the formation rate, with its terminal half-life being similar to that of Adriamycin. The relative exposure of DOX-OL compared to Adriamycin, i.e. the ratio between the AUC of DOX-OL and the AUC of Adriamycin, ranges between 0.4 and 0.6 . $[9,10,11,12]$.

Adriamycin has strongest effect in the $\mathrm{S}$ and $\mathrm{M}$ phases of the cell cycle, when it intercalates into the double strand of DNA inhibiting topoisomerase II. The synthesis of nucleic acids is also inhibited by alkylation, iron, zinc and copper chelation, binding to lipids of cell membrane and the change of the cell membrane permeability and the aforementioned formation of free radicals.

Due to the colour of the drug, it can cause pink (reddish) urine, which may appear within 1-48 hours of administration $[13,14]$.

\subsection{Adriamycin toxicity}

The use of Adriamycin is limited largely by its adverse effects. One of the most dangerous adverse effects for the patient is cardiotoxicity, which significantly increases in case of prior use of anthracyclines. The presence of concomitant diseases of the cardiovascular system, prior radiotherapy to the mediastinal area, or associating anthracycline with other cardiotoxic drugs requires special care in therapy based on Adriamycin [15].

There are many factors that can affect myocardial injury. The main predictors affecting the cardiotoxicity of doxorubicin therapy include: arterial hypertension, liver diseases, diabetes, and patient's age - over 65 years of age and under 4 years of age as well as female sex $[16,17,18]$.

The risk of cardiac toxicity during therapy based on Adriamycin increases after the cumulative dose of Adriamycin has been exceeded. The cumulative dose equals $550 \mathrm{mg} / \mathrm{m}^{2}$ or $450 \mathrm{mg} / \mathrm{m}^{2}$ in case of prior mediastinal radiotherapy $[19,20]$.

The mechanism of myocardial injury by Adriamycin is related to an increase in oxidative stress associated with impaired mitochondrial function and structure.

The main cause of Adriamycin toxicity is formation of free radicals. They are formed in two mechanisms: nonenzymatic (leading ingredients are Adriamycin-iron ( $\mathrm{Fe}^{3+}$ ) complexes initiating peroxidation of lipids) and enzymatic, as a result of which the hydroxyl radicals and hydrogen peroxide are formed.

Cardiotoxicity of anthracyclines is classified as: acute, chronic or late also known as delayed. 
Acute cardiotoxicity is dose independent. There is a possibility of damage to the heart after a single drug administration as well as after multiple doses of the drug and it is the result of a direct effect of Adriamycin on the myocardium and the effect of histamine and catecholamines release. In the ECG, among others, sinus tachycardia, lowering the wave voltage, widening of the QRS complex and non-specific $\mathrm{T}$ wave changes are observed. Clinically this complication occurs most often in the form of myocarditis, sometimes accompanied by inflammation of the pericardium. It is transient, however, it can lead to life-threatening situations: life-threatening arrhythmias, hypotension, pulmonary edema or heart attack.

Chronic cardiotoxicity occurs in approx. $10 \%$ of patients. It depends on the dose of doxorubicin and may appear during the first year after treatment. It is characterized by a clinical picture based on congestive heart failure with predominant symptoms such as sinus tachycardia, exercise intolerance, peripheral edema, dyspnea at rest, gallop with a loud voice III, pleural effusion, the jugular venous distension or right-sided heart failure. Delayed cardiotoxicity occurring in approx. 5\% of patients may appear up to 10 years after the end of treatment. It is dose and time since the end of treatment with anthracyclines independent. The clinical picture is characterized by worsening of heart failure symptoms, decrease in ejection fraction and cardiac arrhythmias. In $80 \%$ of patients with delayed cardiotoxicity abnormal diastolic function and exercise intolerance was observed, in almost 50\% - an abnormal myocardial muscle mass and $23 \%$ of patients had impaired systolic function. Ultimately, this leads to dilated cardiomyopathy.

Protective procedures which may reduce the risk of developing cardiotoxicity with anthracycline-based therapy include: maintaining the dose below the cumulative dose level and monitoring of patients with echocardiogram tests or radionuclide angiography tests (MUGA multi gated acquisition scan) $[16,17,18]$.

Another limitation in the use of therapies involving Adriamycin is its hepatotoxicity, defined as the liver damage associated with dysfunction of this organ, caused by exposure to a drug or other non-infectious agent [21].The liver plays an important role in numerous body functions - metabolism, detoxification, storing and elimination (neutralization of most drugs). The aetiology of the liver damage in Adriamycin-based chemotherapy is varied and has been linked to the adverse effects of cytostatic agents, viral infection, hepatitis sepsis, infiltration by tumour or a concomitant primary liver disease. Other factors affecting the liver function include a reaction to antibiotics, analgesics, antiemetics, and other drugs, as well as concomitant diseases, immunosuppression, nutritional deficits or total parenteral nutrition [22].
Adriamycin damages the liver by various causative mechanisms. A few of them have been thoroughly understood, and in-depth explanation of the majority of them requires further research.

The liver is responsible for the uptake and metabolism of most drugs. A number of membrane-bound and cytosolic enzymes, related to the endoplasmatic reticulum, are involved in the processes. Adriamycin has a specific pathway of biotransformation, involving one or more enzyme systems [23].

Most of the drugs and their metabolites are excreted by the kidneys or in the bile, which requires a good drug solubility in water while the medications taken by the oral route have rather lipophilic properties and are not soluble in water. Adriamycin and its metabolites are excreted from the body in the bile. Metabolic processes occurring in the liver, known as the first and second phase reaction, lead to a change in the nature of these compounds from lipophilic to hydrophilic. Adriamycin is poorly absorbed when administered by oral route, but when administered by iv rout is rapidly eliminated from plasma [24].

Hepatotoxic effects of drugs cause hepatocyte necrosis. Some drugs can damage vascular endothelial cells, stellate cells or epithelial cells in the small bile ducts leading to the development of cholestasis [25].

Reactions to hepatocellular injuries can be divided into two categories, namely:

- chemical reactions,

- idiosyncratic reactions or immune hypersensitivity.

Several mechanisms resulting in the damage to the hepatocytes have been studied. It has been proven that a permanent bond of toxic metabolite and hepatocyte organelles may interfere with proper functioning of the whole cell and may lead to its necrosis or apoptosis [26].

Hepatocyte damage may also occur while stimulating the apoptotic pathway by the drug or its metabolite. In this case, the drug serves as a ligand for the receptors of tumour necrosis factor $\alpha$ (TNF- $\alpha$ ) or Fas $[27,28]$.

Studies on Adriamycin show that there is an increased level of transaminases in $40 \%$ of patients treated with Adriamycin, but it is transient and asymptomatic and returning to the initial state even when the treatment is continued. There are few reports of cases of acute liver injury with symptoms and jaundice during treatment with Adriamycin. In most of these cases the patients received a combination therapy with Adriamycin and other chemotherapeutic agents. It is believed that the anthracycline antibiotics increase toxicity of other drugs, such as cyclophosphamides, methotrexates, and mercaptopurine. Multidrug antineoplastic treatment regimens may cause hepatic sinusoidal obstruction syndrome (SOS) formerly termed veno-occlusive disease of the liver (VOD), but the 
Adriamycin role in this process is not clear. While cases of hepatotoxic liver damage caused by Adriamycin are rare, they are likely due to the direct toxicity of Adriamycin to the liver cells. Adriamycin and its analogues are metabolized in the liver via microsomal enzymes. However, the production of toxins and immunogenic intermediate metabolites can cause liver injury. The severity of liver injury associated with the Adriamycin therapy is usually mild. Adriamycin therapies have not been directly linked to acute liver failure, chronic hepatitis or vanishing bile duct syndrome. There is no information on cross sensitivity to hepatic injury among the various cytotoxic antibiotics, but some degree of cross reactivity should be assumed [29,30,31].

\subsection{Liposomal Adriamycin (doxorubicins) - the mechanism of action, toxicity}

Knowledge and studies on cancer diseases and their course contributed to a successive creation of two improved forms of doxorubicin - non-pegylated and pegylated formulas of the drug [32].The mechanism of anticancer effects of liposomal Adriamycin is similar to the mechanism of conventional Adriamycin - inhibition of topoisomerase II, and of DNA and RNA polymerase, production of free radicals and membrane binding. Placing of molecules of the active substance in liposomes has significant influence on the distribution of the drug, unlike in the classical form of doxorubicin hydrochloride. Animal studies demonstrated that liposomal forms of anthracyclines show a reduced distribution to myocardial cells, to gastric mucosa and intestine, while maintaining the same cytotoxic effectiveness in the tumour cells. This is due to the fact that liposomes administered intravenously are not able to leave the circulatory system through proper capillaries (such as those, for example, in the myocardium), while easily escape to the surrounding cells via not properly formed and defective vessels in the tumour. The pharmacokinetic profile of the drug indicates that the doxorubicin clearance from the blood is dependent on the liposomal carrier - doxorubicin becomes available only after liposomes are extravasated from the circulation to the tissue compartment. The liposomal shell is made of phosphatidylcholine molecules and cholesterol. To improve the distribution of the drug a special form of liposomal doxorubicin was created, by covering the surface of liposomes with a hydrophilic polymer - methoxy polyethylene glycol (MPEG). This process, known as pegylation, reduces the interaction between the lipid bilayer membrane and the plasma components, and thereby prevents the molecules from the destructive actions of mononuclear phagocytes, resulting in prolongation of the drug presence in the blood. Non-pegylated formula of the drug releases more than half of doxorubicin contained therein within one hour after administration, and more than $90 \%$ within 24 hours after injection [33]. When non-pegylated form of the drug is administered, only $10 \%$ of doxorubicin contained in the coating liposomal shell is released within 24 hours after infusion [34]. Pegylated form of the drug is associated with a higher incidence of acute complications. Modifications related to the structure of liposomal doxorubicin molecules aim at maximizing the activity of the drug within the tumour tissue and reducing its adverse effects, including reducing of risk of cardiac toxicity during treatment, which has been proven both in preclinical studies in animals, as well as later in the clinical trials $[35,36,37,38]$.

Administration of liposomal doxorubicin is also burdened with many adverse effects, of which the most common are: fatigue, nausea, vomiting, inflammation of the mucous membranes of the mouth, diarrhoea, neutropenia, thrombocytopenia, anaemia, alopecia and erythema. During therapy with pegylated liposomal doxorubicin approx. $40 \%$ of patients participating in clinical trials for breast cancer and ovarian cancer reported this symptom. Characteristic symptoms of palmar-plantar erythrodysesthesia (EPP) is presence (depending on the severity) of painful blisters or swelling of palms and feet. In most reported cases it has been mild. Severe cases (grade III and IV) were recorded in less than $20 \%$ of patients. The occurrence of PPE was observed usually after several cycles of treatment [39].

The incidence of inflammation of the mucous membranes of the mouth, nausea, vomiting, diarrhoea, fatigue in randomized phase III trials is similar for schemes containing non-pegylated liposomal doxorubicin compared with schemes with conventional doxorubicin, and the incidence and severity of alopecia - smaller [40].

\section{Summary}

Anthracycline-based therapies are widely used in the treatment of systemic breast cancer, ovarian cancer, sarcomas, leukaemias and lymphomas. A significant limitation of these therapies are the adverse effects: cardiotoxicity largely dependent on the cumulative dose and hepatotoxicity giving a picture of liver injury associated with impaired function of this organ. Scientific progresshas led to the creation of two improved forms of Adriamycin. A formula with a unique mechanism of action is NPLD - non-pegylated liposomal doxorubicin, which turned out to be a drug with efficacy comparable to conventional anthracyclines, but burdened with a much lower risk of cardiotoxicity. It has been shown that with the use of NPLD higher cumulative doses of the drug can be safely administered than with conventional anthracyclines. The second improved form of Adriamycin is a form designed to increase drug distribution, prepared by coating the liposome surface with a hydrophilic polymer - methoxy polyethylene glycol (MPEG). This process, known as pegy- 
lation, reduces the interaction between the lipid bilayer membrane and the plasma components, and thereby prevents the molecules from the destructive actions of mononuclear phagocytes, resulting in prolongation of the drug presence in the blood. Despite the modifications within the structure of liposomal doxorubicin molecules in order to maximize the activity of the drug in the tumour tissue, there are still considerable limitations in the use of these forms of therapy due to the incidence rate of adverse events.

\section{Adriamycyna}

Adriamycyna (doksorubicyna) należy do grupy antracyklin o silnym działaniu przeciwnowotworowym. Wyizolowana została po raz pierwszy z kultury bakterii Streptomyces peucetius var. caesius przez Arcamone a zarejestrowana, jako lek w 1971 roku [1].

Adriamycyna jest substancją chemiczną, której mechanizm działania jest cyklozależny, fazowo-specyficzny, polegający na tworzeniu nieprawidłowych wiązań pomiędzy zasadami azotowymi DNA oraz hamowaniu kluczowych enzymów syntezy DNA - topoizomerazy I i II oraz tworzeniu wolnych rodników uszkadzających DNA. Dzięki tym wysoko selektywnym właściwościom, Adriamycyna ma bardzo szerokie zastosowanie w onkologii i hematologii [2], jednak jej mechanizm działania przeciwnowotworowego nie jest do końca poznany. Z pewnością zahamowanie syntezy białek oraz DNA i RNA jest odpowiedzialne za większość cytotoksycznych efektów działania Adriamycyny.

Zasada działania Adriamycyny polega na wbudowywaniu się $\mathrm{w}$ strukturę DNA powodując rozerwanie i fragmentację helisy, co w prostej drodze prowadzi do zahamowania replikacji DNA oraz uniemożliwia transkrypcję DNA na RNA.

Hipotetycznie wstawienie cząsteczki antracykliny między sąsiednie pary zasad w podwójnej helisie DNA uniemożliwia jej rozwinięcie konieczne do dalszej replikacji [3].

Adriamycyna, jako lek przeciwnowotworowy, ma zastosowanie w leczeniu systemowym nowotworów piersi, jajnika, mięsaków, białaczek, chłoniaków [4].

Podaje się ją dożylnie lub dotętniczo we wlewie kroplowym. Niekiedy może być podawana również miejscowo: - do guza [5],

- do pęcherza moczowego [6],

- dootrzewnowo [7],

- doopłucnowo w przypadku międzybłonniaka złośliwego opłucnej[8].

\subsection{Właściwości farmakokinetyczne i farmakodynamiczne}

Klirens osoczowy Adriamycyny mieści się w zakresie od 324 do $809 \mathrm{ml} / \mathrm{min} / \mathrm{m}^{2}$. Substancja ta jest eliminowana $\mathrm{z}$ osocza przede wszystkim w postaci metabolitu doksorubicynolu (DOX-OL) i wydalana z żółcią. Około 40\% dawki pojawia się w żółci w ciągu 5 dni, natomiast jedynie od 5 do $12 \%$ leku i jego metabolitów pojawia się w tym samym okre- sie $\mathrm{w}$ moczu. W moczu odzyskiwano $<3 \%$ dawki w postaci doksorubicynolu (DOX-OL) przez 7 dni.

Początkowy okres półtrwania Adriamycyny w fazie dystrybucji wynosi około 5 minut, co wskazuje na szybki wychwyt tej substancji przez tkanki. Natomiast jej wolna eliminacja z tkanek znajduje odzwierciedlenie w długości okresu półtrwania w fazie końcowej, który wynosi od 20 do 48 godzin. Objętość dystrybucji w stanie równowagi waha się od 809 do $1214 \mathrm{l} / \mathrm{m}^{2}$, co wskazuje na znaczny wychwyt leku przez tkanki. Stopień związania z białkami osocza i jej głównego metabolitu, wynosi około 74 - 76\% i nie zależy od stężenia w osoczu do stężenia $1,1 \mu \mathrm{g} / \mathrm{ml}$.

Obserwowano przenikanie Adriamycyny do mleka matki, przy czym maksymalne stężenie w mleku stwierdzane po 24 godzinach od zastosowania leczenia było około 4,4 razy większe niż odpowiednie stężenie w osoczu. Adriamycynę wykrywano w mleku w okresie do 72 godzin po zastosowaniu tego leku w dawce $70 \mathrm{mg} / \mathrm{m}^{2}$.

Adriamycyna nie przenika bariery krew - mózg.

W wyniku redukcji enzymatycznej i odszczepienia reszty cukrowej daunozaminy powstają aglikony. Procesowi temu towarzyszy powstawanie wolnych rodników, których miejscowe wytwarzanie może się przyczyniać do kardiotoksycznego działania Adriamycyny. Dystrybucja (DOX-OL) w organizmie pacjentów jest ograniczana szybkością jego powstawania, przy czym jego okres półtrwania w fazie końcowej jest podobny jak w przypadku Adriamycyny. Względna wielkość ekspozycji na DOX-OL w porównaniu do Adriamycyny, tj. stosunek AUC DOX-OL do AUC Adriamycyny, waha się od 0,4 do 0,6. [9,10,11,12]. Adriamycyna najsilniej działa w fazie S i M cyklu komórkowego, wbudowując się pomiędzy podwójną nić DNA i hamując działanie topoizomerazy II. Syntezę kwasów nukleinowych hamuje także na drodze alkilacji, chelatowania jonów żelaza, cynku i miedzi, wiązania się z lipidami błony komórkowej i zmianą jej przepuszczalności oraz wspomnianego już tworzenia się wolnych rodników.

Ze względu na kolor leku, może powodować różowe (czerwonawe) zabarwienie moczu, które może pojawić się w ciągu 1-48 godzin od podania [13,14].

\subsection{Toksyczność Adriamycyny}

Stosowanie Adriamycyny ograniczone jest w znacznym stopniu przez działania niepożądane. Jednym z najbardziej niebezpiecznych dla pacjenta jest kardiotoksyczność, która istotnie wzrasta w przypadku wcześniejszego 
stosowania antracyklin. Występowanie współistniejących chorób układu sercowo-naczyniowego, wcześniejszej radioterapii $\mathrm{w}$ obszarze śródpiersia lub $\mathrm{w}$ przypadku kojarzenia antracyklin z innymi kardiotoksycznymi lekami nakazuje szczególną ostrożność w zastosowaniu terapii opartej na Adriamycynie [15].

Istnieje wiele czynników, które mogą wpływać na uszkodzenie mięśnia sercowego. Jako główne predykatory mające wpływ na kardiotoksyczność terapii doksorubicyną należy wymienić: nadciśnienie tętnicze, choroby wątroby, cukrzycę oraz wiek pacjenta - powyżej 65 roku życia i poniżej 4 roku życia oraz płeć żeńską $[16,17,18]$.

Ryzyko wystąpienia kardiotoksyczności podczas stosowania terapii opartej na Adriamycynie wzrasta po przekroczeniu dawki kumulacyjnej Adriamycyny. Dawka ta wynosi $550 \mathrm{mg} / \mathrm{m}^{2}$ lub $450 \mathrm{mg} / \mathrm{m}^{2}$ w przypadku uprzedniej radioterapii na śródpiersie $[19,20]$.

Mechanizm uszkodzenia mięśnia sercowego przez Adriamycynę polega na wywoływaniu stresu oksydacyjnego związanego $\mathrm{z}$ zaburzeniami funkcji i struktury mitochondriów.

Główną przyczyną toksyczności Adriamycyny jest powstawanie wolnych rodników. Powstają one w dwóch mechanizmach - nieenzymatycznym (składnikami wiodącymi są kompleksy Adriamycyna-żelazo $\left(\mathrm{Fe}^{3+}\right)$ rozpoczynające peroksydację lipidów) oraz enzymatycznym, w wyniku którego powstają wolne rodniki hydroksylowe i nadtlenek wodoru.

Przyjęty został podział kardiotoksyczności antracyklin na ostrą, przewlekłą oraz późną, inaczej nazywaną odległą.

Kardiotoksyczność ostra jest niezależna od dawki leku, istnieje możliwość uszkodzenia serca po jednym podaniu, jak również po wielu dawkach leku i jest to wynik bezpośredniego działania Adriamycyny na mięsień sercowy i jego uszkodzenia oraz działania uwalnianych katecholamin i histaminy. W zapisie EKG obserwuje się między innymi tachykardię zatokową, obniżenie woltażu załamków, poszerzenie zespołu QRS oraz nieswoiste zmiany załamka T. Klinicznie powikłanie najczęściej przebiega pod postacią zapalenia mięśnia sercowego, czasem z towarzyszącym zapaleniem osierdzia. Ma charakter przemijający, może jednak prowadzić do stanów zagrażających życiu - groźnych zaburzeń rytmu, hipotonii, obrzęku płuc czy zawału serca.

Kardiotoksyczność przewlekła występująca u ok. $10 \%$ chorych jest zależna od dawki doksorubicyny i może ujawnić się w ciągu pierwszego roku po zakończeniu terapii. Charakteryzuje się obrazem klinicznym opartym na zastoinowej niewydolności serca $\mathrm{z}$ dominującymi objawami takimi jak: tachykardia zatokowa, nietolerancja wysiłku, obrzęki obwodowe, duszność spoczynkowa, rytm cwałowy z głośnym III tonem, wysięk opłucnowy, poszerzenie żył szyjnych, prawokomorowa niewydolność serca. Kardiotoksyczność odległa występująca u ok. 5\% pacjentów może pojawiać się po 10 latach od zakończenia terapii i jest niezależna od dawki leku i czasu od zakończenia leczenia antracyklinami. Obraz kliniczny charakteryzuje się zaostrzeniem niewydolności serca, spadku frakcji wyrzutowej oraz zaburzeń rytmu serca. U 80\% chorych z kardiotoksycznością odległą obserwuje się nieprawidłową funkcję rozkurczową i nietolerancję wysiłku, u prawie $50 \%$ - nieprawidłową masę mięśnia sercowego a $23 \%$ chorych ma zaburzenia funkcji skurczowej. Ostatecznie prowadzi do kardiomiopatii rozstrzeniowej.

Zabiegami protekcyjnymi, które mogą obniżyć ryzyko rozwoju kardiotoksyczności podczas terapii opartej na antracyklinach są nieprzekraczanie dawki kumulacyjnej oraz monitorowanie pacjentów poddawanych badaniom ECHO serca lub angiokardiografii izotopowej (MUGA - multi gated acquisition scan) $[16,17,18]$.

Kolejnym ograniczeniem w stosowaniu terapii z udziałem Adriamycyny jest jej hepatotoksyczność, określana, jako uszkodzenie wątroby związane z upośledzoną funkcją tego narządu, spowodowane ekspozycją na lek lub inny czynnik nieinfekcyjny [21]. Wątroba pełni w organizmie liczne funkcje - metaboliczną, detoksykacyjną, magazynującą i eliminacyjną (neutralizacja większości leków). Etiologia uszkodzenia wątroby podczas chemioterapii opartej na Adriamycynie jest zróżnicowana i wiąże się m.in. z niepożądanym działaniem cytostatyków, zakażeniem wirusowym, zapaleniem wątroby w przebiegu posocznicy, naciekami nowotworowymi czy współistniejącą pierwotną chorobą wątroby. Inne czynniki wpływające na funkcję wątroby to reakcja na antybiotyki, leki przeciwbólowe, przeciwwymiotne i inne, a także na choroby współistniejące, immunosupresję, deficyty żywieniowe czy całkowite żywienie pozajelitowe[22].

Adriamycyna uszkadza wątrobę na drodze różnych mechanizmów sprawczych. Niewielka ich część została dokładnie poznana, a dogłębne wyjaśnienie większości z nich wymaga dalszych badań.

W wątrobie następuje wychwyt i metabolizm większości leków, dzieje się to za pośrednictwem wielu enzymów błonowych oraz cytozolowych, związanych z siatką endoplazmatyczną. Adriamycyna ma specyficzny szlak biotransformacji, wykorzystujący jeden lub kilka układów enzymatycznych [23].

Większość leków i ich metabolitów jest wydalana z organizmu przez nerki lub wydzielana z żółcią, co wymaga ich dobrej rozpuszczalności w wodzie, podczas gdy leki przyjmowane drogą doustną wykazują właściwości lipofilne i nie rozpuszczają się w wodzie. Adriamycyna i jej metabolity wydalane są z organizmu z żółcią. Przemiany metaboliczne zachodzące $\mathrm{w}$ wątrobie, określane mianem reakcji pierwszej i drugiej fazy, prowadzą do zmiany charak- 
teru tych związków z lipofilnego na hydrofilny. Adriamycyna słabo się wchłania po podaniu p.o., natomiast podana we wstrzyknięciu i.v. jest szybko eliminowana z osocza [24].

Hepatotoksyczne efekty działania leków powodują zmiany martwicze hepatocytów. Niektóre leki mogą uszkadzać komórki śródbłonka naczyniowego, gwiaździste lub nabłonka małych przewodów żółciowych, powodując rozwój cholestazy [25].

Reakcje uszkodzenia komórek wątrobowych można podzielić na dwie kategorie, czyli:

- chemiczne,

- idiosynkrazji lub immunologicznej nadwrażliwości.

Przebadano kilka mechanizmów, w wyniku, których dochodzi do uszkodzenia hepatocytów. Udowodniono, że trwałe połączenie toksycznego metabolitu $\mathrm{z}$ organellami hepatocytu może zaburzać właściwe funkcjonowanie całej komórki i prowadzić do jej martwicy lub apoptozy [26].

Do uszkodzenia hepatocytu może dojść również na drodze stymulacji szlaku apoptozy przez lek lub jego metabolit. $\mathrm{W}$ takim przypadku lek odgrywa rolę liganda dla receptorów czynnika martwicy nowotworów $\alpha$ (ang. tumour necrosis factor $\alpha-$ TNF- $\alpha$ ) lub Fas $[27,28]$.

Badania nad Adriamycyną pokazują, że zwiększony poziom aminotransferaz występuje u do $40 \%$ pacjentów leczonych Adriamycyną, ale jest przemijający i przebiega bezobjawowo, powracający do stanu początkowego nawet przy kontynuacji leczenia. Są nieliczne doniesienia o przypadkach ostrego uszkodzenia wątroby z objawami i żółtaczką w trakcie leczenia Adriamycyną. W większości tych przypadków pacjenci otrzymywali leczenie złożone z Adriamycyny i innych chemioterapeutyków. Uważa się, że antybiotyki antracyklinowe zwiększają toksyczność innych leków takich jak: cyklofosfamid, metotreksat i merkaptopuryna. Wielolekowe schematy leczenia przeciwnowotworowego mogą powodować zespół niedrożności zator wątrobowy dawniej nazywany chorobą wenookluzyjna wątroby, ale rola Adriamycyny $\mathrm{w}$ tym procesie nie jest jasna. 0 ile hepatotoksyczne uszkodzenia wątroby spowodowane Adriamycyną są rzadkie, to prawdopodobnie spowodowane są one bezpośrednią toksycznością Adriamycyny na komórki wątroby. Adriamycyna i jej analogi są metabolizowane w wątrobie przez enzymy mikrosomalne, natomiast produkcja toksyn i immunogenicznych pośrednich metabolitów może spowodować uszkodzenie wątroby. Nasilenie uszkodzenia wątroby związane $\mathrm{z}$ terapią Adriamycyną ma zwykle łagodny przebieg. Terapie Adriamycyną nie zostały bezpośrednio powiązane z ostrą niewydolnością wątroby, przewlekłym zapaleniem wątroby lub zespołem znikających przewodów żółciowych. Nie ma informacji o wzajemnej wrażliwości krzyżowej na uszkodzenia wątroby wśród różnych antybiotyków cytotoksycznych, ale należy przyjąć pewien stopień reaktywności krzyżowej [29,30,31].
1.3.Adriamycyny (doksorubicyny) liposomalne mechanizm działania, toksyczność.

Wiedza i nauka o chorobach nowotworowych oraz ich przebiegu przyczyniły się do powstania kolejno dwóch ulepszonych form doksorubicyny - niepegylowanej i pegylowanej formuły tego leku [32]. Sposób działania przeciwnowotworowego doksorubicyny liposomalnej jest analogiczny do mechanizmu doksorubicyny konwencjonalnej - hamowanie topoizomerazy II, polimerazy DNA oraz RNA, wytwarzanie wolnych rodników oraz wiązanie z błoną komórkową. Umieszczenie cząsteczek substancji czynnej w liposomach ma znaczący wpływ na dystrybucję leku, inaczej niż w przypadku klasycznej formy chlorowodorku doksorubicyny. W badaniach przeprowadzanych na zwierzętach udowodniono, że liposomalne postacie antracyklin wykazują zmniejszoną dystrybucję do komórek mięśnia sercowego, błony śluzowej żołądka oraz jelit, zachowując jednocześnie jednakową skuteczność cytotoksyczną w komórkach guza nowotworowego. Wynika to z faktu, że podane dożylnie liposomy nie są w stanie opuścić krążenia poprzez prawidłowe kapilary (takie jak występujące na przykład w mięśniu sercowym), natomiast bez problemu wydostają się one do otaczających komórek przez nieprawidłowo zbudowane oraz przeciekające naczynia w obrębie guza nowotworowego. Profil farmakokinetyczny leku wskazuje, że klirens doksorubicyny z krwi jest zależny od nośnika liposomalnego - doksorubicyna staje się dostępna dopiero po przejściu liposomów z krążenia do kompartmentu tkankowego. Otoczka liposomalna jest zbudowana z cząsteczek fosfatydylocholiny oraz cholesterolu. Aby dodatkowo zwiększyć dystrybucję leku, wytworzono także specjalną formę liposomalnej doksorubicyny poprzez pokrycie powierzchni liposomów hydrofilowym polimerem - metoksypolietylenoglikolem (MPEG). Proces ten, nazywany pegylacją, powoduje zmniejszenie interakcji między podwójną warstwą lipidową a składnikami osocza, a tym samym zabezpiecza cząsteczki przed niszczącym działaniem fagocytów jednojądrzastych, powodując wydłużenie obecności leku we krwi. Niepegylowana postać leku uwalnia ponad połowę zawartej w niej doksorubicyny w ciągu godziny od podania i ponad $90 \%$ w ciągu 24 godzin od wstrzyknięcia [33]. Podczas podania niepegylowanej formy leku w ciągu 24 godzin od infuzji uwalniane jest zaledwie $10 \%$ zawartej w otoczce liposomalnej doksorubicyny [34]. Forma pegylowana leku związana jest z częstszym występowaniem ostrych powikłań. Modyfikacje związane z budową cząsteczek doksorubicyn liposomalnych mają na celu maksymalne zwiększenie aktywności leku w obrębie tkanki nowotworowej oraz ograniczenie występowania działań niepożądanych, w tym zmniejszenie ryzyka kardiotoksyczności w przebiegu leczenia, co zostało udowodnione zarówno w badaniach przedklinicz- 
nych na zwierzętach, jak również później w badaniach klinicznych [35,36,37,38].

Podanie doksorubicyny liposomalnej obarczone jest również wieloma działaniami niepożądanymi, najczęściej spotykane to: osłabienie, nudności, wymioty, zapalenie błony śluzowej jamy ustnej, biegunka, neutropenia, trombocytopenia, niedokrwistość, łysienie oraz rumień skórny. Podczas terapii pegylowaną liposomalną doksorubicyną ok. $40 \%$ pacjentek biorących udział w badaniach klinicznych raka piersi i jajnika zgłaszało ten objaw. Charakterystycznymi cechami rumienia dłoni i podeszew stóp (PPE, palmar-plantar erythrodysesthesia) jest występowanie, w zależności od stopnia nasilenia, bolesnych pęcherzy i obrzęków na dłoniach i stopach. W większości przypadków miał łagodny przebieg. Postać ciężką (stopień III i IV) odnotowano w mniej niż 20\% przypadków. Wystąpienie PPE obserwowano zazwyczaj po kilku cyklach leczenia [39].

Częstość występowania zapalenia błon śluzowych jamy ustnej, nudności, wymiotów, biegunki, zmęczenia w randomizowanych badaniach III fazy jest dla schematów zawierających niepegylowaną doksorubicynę liposomalną podobna w porównaniu ze schematami z doksorubicyną konwencjonalną, a częstość oraz nasilenie łysienia mniejsze [40].

\section{Podsumowanie}

Terapie oparte na antracyklinach mają szerokie zastosowanie w leczeniu systemowym nowotworów piersi, jajnika, mięsaków, białaczek i chłoniaków. Znacznym ograniczeniem tych terapii są działania niepożądane: kardiotoksyczność w dużej mierze zależna od dawki kumulacyjnej oraz hepatotoksyczność, dająca obraz uszkodzenia wątroby powiązanego z upośledzoną funkcją tego narządu. Postępy w nauce doprowadziły do powstania dwóch ulepszonych form Adriamycyny. Preparatem o unikatowym mechanizmie działania jest NPLD niepegylowana doksorubicyna liposomalna, która okazała się lekiem o skuteczności porównywalnej do antracyklin konwencjonalnych, ale obarczonym znacznie mniejszym ryzykiem kardiotoksyczności. Wykazano, że przy zastosowaniu NPLD możliwe jest bezpieczne zastosowanie wyższych dawek skumulowanych niż ma to miejsce dla antracyklin konwencjonalnych. Drugą ulepszoną formą Adriamycyny jest postać stworzona w celu zwiększenia dystrybucji leku, wytworzona poprzez pokrycie powierzchni liposomów hydrofilowym polimerem - metoksypolietylenoglikolem (MPEG). Proces ten, nazywany pegylacją, powoduje zmniejszenie interakcji między podwójną warstwą lipidową a składnikami osocza, a tym samym zabezpiecza cząsteczki przed niszczącym działaniem fagocytów jednojądrzastych, powodując wydłużenie obecności leku we krwi. Pomimo modyfikacji związanych z budową cząsteczek doksorubicyn liposomalnych mających na celu maksymalne zwiększenie aktywności leku w obrębie tkanki nowotworowej nadal mamy do czynienia ze znacznym ograniczeniem stosowania tych form preparatu ze względu na występowanie działań niepożądanych.

\section{Conflict of interest}

The authors have declared no conflict of interest.

\section{References:}

1. Wallace K.B.: Doxorubicin-induced cardiac mitochondriopathy. Pharmacology \& Toxicology 2003; 93:105-115.

2. Denisso T., Kowalski D.M.: Przegląd leków stosowanych w onkologii. W. Krzakowski M. (ed.) Onkologia Kliniczna. Bogris Wydawnictwo Medyczne, Warszawa 2006; 235-244.

3. Gniazdowski M., Szmigiero L.: Molekularne mechanizmy oddziaływania związków przeciwnowotworowych na DNA. Na Pograniczu Chemii i Biologii, 2003; 7: 45-73.

4. Kufe D.W., Holland J.F., Frei E.: Cancer Medicine 6., BC Decker, Hamilton 2003.

5. Jarząbek M., Jargiełło T., Janczarek M., Pyra K., Wolski A., Budzyńska A., Szczerbo-Trojanowska M.: Leczenie guzów przerzutowych $\mathrm{w}$ wątrobie za pomocą wewnątrznaczyniowej chemoembolizacji z użyciem mikrocząstek nasączonych cytostatykiem (DEMTACE).Wydawnictwo Borgis - Postępy Nauk Medycznych 5/2012;446-450.

6. Polskie Towarzystwo Urologiczne: Zasady postępowania u chorych na raka pęcherza moczowego. Warszawa 2002.

7. Milczek T., Emerich J., Klasa-Mazurkiewicz D.: Chemioterapia dootrzewnowa w leczeniu chorych na raka jajnika. Curr. Gynecol. Oncol. 2009; 7 (4): 270-281.

8. Wcisło G., Korniluk J., Szarlej-Wcisło K., Pawlak W.Z., Nurzyński P., Duchnowska R.: Leczenie chorób nowotworowych czynnikiem martwicy nowotworów - alfa (TNF-alfa). Współczesna Onkologia, 2002; 4: 222-227.

9. Gabizon et al. Pharmacokinetics of Pegylated Liposomal Doxorubicin Review of Animal and Human Studies. Clin Pharmacokinet 2003; 42 (5): 419-436.

10. National Institute for Health and Clinical Excellence; TA91 Ovarian cancer (advanced) - paclitaxel, pegylated liposomal doxorubicin hydrochloride and topotecan (review): Guidance; 25 May 2005.

11. Gordon AN, Fleagle JT, Guthrie D, Parkin DE, Gore ME, Lacave AJ. Recurrent epithelial ovarian carcinoma: a randomized phase III study of pegylated liposomal doxorubicin versus topotecan. J Clin Oncol. 2001;19:3312-3322.

12. Gordon A.N., Tonda M., Sun S., Rackoff W.: Long-term survival advantage for women with pegylated liposomal doxorubicin compared with topotecan in a phase 3 randomized study of recurrent and refractory epithelial ovarian cancer. Gynecol Oncol. 2004; 95:1-8.

13. Podlewski J.K., Chwalibogowska - Podlewska A.: Leki współczesnej terapii. Medical Tribune Polska, Warszawa 2009; 270-271; 288-289.

14. Dwyer Schull P. (ed.). The oncology drug \& regiments. New York. Elsevier Oncology 2006; 128-131; 139-143.

15. Wilkers G.M., Barton-Burke M.: Oncology nursing drug handbook 2010. Jones and Bartlett Publishers. Sadbury 2010; 151-154; 163-168

16. Deptała A., Omyła-Staszewska J., Staszewska-Skurczyńska M.: Kardiotoksyczność antracyklin i kardioprotekcja. Fakty i mity. Wsp. Onkol. 2004; 8: 107-111. 
17. Szmit S., Grabowski M.: Powikłania kardiologiczne leczenia raka piersi. Terapia 2008; 16: 46-55.

18. Szmit S., Główczyńska R., Szczylik C., Opolski G.: Niewydolność serca po chemioterapii. Terapia 2007; 15: 77-87.

19. Wilkers G.M., Barton-Burke M.: Oncology nursing drug handbook 2010. Jones and Bartlett Publishers. Sadbury 2010; 151-154; 163-168.

20. Dwyer Schull P. (ed.). The oncology drug \& regiments. New York. Elsevier Oncology 2006; 128-131; 139-143.

21. Navarro V.J, Senior J.R.: Drug-related hepatotoxicity. N Engl J Med. 2006; 354: 731-9.

22. King P.D., Perry M.C.: Hepatotoxicity of chemotherapy. Oncologist 2001; 6: 162-76.

23. Gonzalez F.J., Turkey R.H.: Drug metabolism. In: Brunton L.L., Lazo J.S., Parker K.L., editors. Goodman \& Gilmans the pharmacological basis of therapeutics. Eleventh ed. New York, McGraw-Hill: Medical Publishing Division. 2006; 71-91.

24. Gabizon et al:: Pharmacokinetics of Pegylated Liposomal Doxorubicin Review of Animal and Human Studies. Clin Pharmacokinet 2003; 42 (5): 419-436.

25. Gunawan B.K., Kaplowitz N.: Clinical perspectives on xenobioticinduced hepatotoxicity. Drug Metab Rev 2004; 36: 301-12.

26. Liu Z.X., Kaplowitz N.: Immune-mediated drug-induced liver disease. Clin Liver Dis 2002; 6: 755-74.

27. Gunawan B.K., Kaplowitz N.: Mechanisms of drug-induced liver disease. Clin Liver Dis 2007; 11: 459-75.

28. Hartleb M.: Polekowe uszkodzenia wątroby. Terapia 2008; 16: 67-74.

29. Ma B., Yeo W., Hui P., Ho W.M., Johnson P.J.: Acute toxicity of adjuvant doxorubicin and cyclophosphamide for early breast cancer - a retrospective review of Chinese patients and comparison with an historic Western series. Radiother Oncol 2002; 62: 185-189.

30. Chalasani N., Fontana R.J., Bonkovsky H.L., Watkins P.B., Davern T., Serrano J., Yang H., Rochon J.; Drug Induced Liver Injury Network (DILIN). Causes, clinical features, and outcomes from a prospective study of drug-induced liver injury in the United States. Gastroenterology 2008; 135: 1924-1934.

31. Reuben A., Koch D.G., Lee W.M.; Acute Liver Failure Study Group. Drug-induced acute liver failure: results of a U.S. multicenter, prospective study. Hepatology 2010; 52: 2065-2076.

32. Pieńkowski T. Rak piersi. W: Krzakowski M. (ed.) Onkologia kliniczna. Bogris Wydawnictwo Medyczne, Warszawa 2006; 1014-1056.
33. Waterhouse D.N., Tardi P.G., Mayer L.D. et al.: A comparison of liposomal formulation of doxorubicin with drug administered in free for: changing toxicity profiles. Drug Saf. 2001; 24:903-920.

34. Gabizon A., Catane R., Uziely B. et al.: Prolonged circulation time and enhanced accumulation in malignant exudates of doxorubicin encapsulated in polyethyleneglycol coated in liposomes. Cancer Res. 1994; 54: 987-992.

35. Rahman A., White G., More N. et al.: Pharmacological, toxicological and therapeutic evaluation in mice of doxorubicin entrapped in cardiolipin liposomes. Cancer Res. 1985; 45: 796-803.

36. Cowens J.W., Creaven P.J., Greco W.R. et al.: Initial clinical (phase I) trial of TLC D-99 (doxorubicin encapsulated in liposomes). Cancer Res. 1993; 53: 2796-802.

37. Safra T., Muggia F., Jeffers S. et al.: Pegylated liposomal doxorubicin (Doxil): reduced clinical cardiotoxicity in patients reaching or exceeding cumulative doses of $500 \mathrm{mg} / \mathrm{m}^{2}$. Ann. Oncol. 2000; 11: 1029-1033.

38. O’Brien M.E., Wigler N., Inbar M. et al:: Reduced cardiotoxicity and comparable efficacy in a phase III trial of pegylated liposomal doxorubicin $\mathrm{HCl}$ (Caelyx/Doxil) versus conventional doxorubicin for first-line treatment of metastatic breast cancer. Ann. Oncol. 2004; 15: 440-449.

39. Waterhouse D.N., Tardi P.G., Mayer L.D. et al.: A comparison of liposomal formulation of doxorubicin with drug administered in free for: changing toxicity profiles. Drug Saf. 2001; 24: 903-920.

40. Harris L., Batist G., Belt R. et al.: Liposome-encapsulated doxorubicin compared with conventional doxorubicin in a randomized multicenter trial as first-line therapy of metastatic breast carcinoma. Cancer 2002; 94: 25-36.

\section{Correspondence address}

Agnieszka Kramkowska mail:kramkowska@yahoo.com. tel. 605270629

Otrzymano: 25.01.2016

Zrecenzowano: 08.02.2016, 22.02.2016

Przyjęto do druku: 26.02.2016 